 \\ DOI: $\underline{10.33716 / \text { bmedj.1038292 }}$}

${ }^{1}$ Dr. Öğr. Üyesi, İzmir Demokrasi Üniversitesi Tıp Fakültesi, Tibbi Mikrobiyoloji Ana Bilim Dalı, İzmir, Türkiye

${ }^{2}$ Arş. Gör., Celal Bayar Üniversitesi Tip Fakültesi, Histoloji ve Embriyoloji Ana Bilim Dalı, Manisa, Türkiye

${ }^{1}$ Prof. Dr., İzmir Demokrasi Üniversitesi Tıp Fakültesi, Tıbbi Mikrobiyoloji Ana Bilim Dalı, İzmir, Türkiye

${ }^{2}$ Prof. Dr., Celal Bayar Üniversitesi Tıp Fakültesi, Histoloji ve Embriyoloji Ana Bilim Dalı, Manisa, Türkiye

Sorumlu Yazar: Emine Müge Karakayalı, Dr. Öğr. Üyesi, İzmir Demokrasi Üniversitesi Tip Fakültesi, Tibbi Mikrobiyoloji Ana Bilim Dalı, İzmir, Türkiye. E-mail: muge.karakayali@idu.edu.tr Telefon: +90 5325076296

Başvuru Tarihi: 01.01.2022 Kabul Tarihi: 24.02 .2021 Yayınlanma Tarihi: 28.02.2022

Athf İçin: Emine Müge Karakayalı, Tuna Önal, Zeynep Gülden Sönmez Taner, Mehmet Ibrahim Tuğlu, Probiyotiklerin kültürde mezenkimal kök hücre davranışına etkisi,2022;6(1):7-16.

\section{Probiyotiklerin kültürde mezenkimal kök hücre davranışına etkisi}

\author{
Effect of probiotics on mesenchymal stem cell behavior in culture
}

\author{
Emine Müge Karakayalı ${ }^{1}$ (D) Tuna Önal², (D) Zeynep Gülden Sönmez Taner ${ }^{1}$, \\ (iD) Mehmet İbrahim Tuğlu²
}

\section{ABSTRACT}

Aim: Probiotic (PB) and Mesenchymal Stem Cell (MSC) are new treatment ideas for diseases. Alterations of microbiata made by PB produce different effects. MSC as the scope of cellular therapy takes place in clinical practice in many diseases such as Graft Versus Host (GVD) within the scope of cellular therapy. In this study, the effects of PB application on MSC behavior in culture in terms of proliferation, migration, differentiation and wound healing were investigated. Material and Method: Frozen adipose tissue-derived (AD) MSC cells were cultured and produced at $2.5 \times 104$ cells/cm2 in a twelve-well culture dish. They were examined for proliferation by MTT, migration by the closure of the wound after the creation of a scratch, and differentiation by transforming the bone cell osteoblast. NBL Probiotic Gold as PB was used as bacteria which include 2.5×109 Enterococcus faecium, 2.5×109lactobacillus acidophilus, 2.5x109lactobacillus rhamnosus, 2.5x109Bifidobacterium longum, 2.5x109Bifidobacterium bifidum and examined in terms of behavioral parameters for MSC in the same environment. The relationship between PB and MSC was also investigated by Scanning Electron Microscopy (SEM). Result: It was determined that use of PB caused an increase in proliferation, faster wound closure by increase of migration and higher differentiation to osteoblast. The ultrastructural examination of MSC by SEM showed that MSCs interacted with PB are more spread, more adherent, and have more active cell morphology. Conclusion: The results showed that the addition of PB to the culture medium increased the MSC efficiency. It was thought that PB would be more beneficial for the clinic to see of MSC if the same positive effect results in studies with experimental animals.

Keywords: Probiyotic; mesenchymal stem cell; culture; behaviour; differentiation

\section{öz}

Amaç: Probiyotik (PB) ve Mezenkimal Kök Hücre (MKH) yeni tedavi fikirleridir. PB ile değiştirilen mikrobiyata farklı etkiler yapmaktadır. Son zamanlarda önemli araştırma konusu olmuştur. MKH hücresel tedavi kapsamında MKH Graft Versus Host (GVH) gibi hastalıklarda klinik uygulamada yerini almaktadır. Bu çalışmada kültür ortamında MKH davranışına çoğalma, göç etme, farklanma ve yara iyileşmesi açılarından PB uygulamasının yapacağı etkiler araştırıldı. Gereç ve Yöntem: Dondurulmuş yağ dokusu kökenli MKH (YDMKH) hücre kültüre alınarak oniki kuyucuklu kültür tabağında 2.5×104hücre/cm2 olacak şekilde üretildi. Çoğalması MTT ile, göç etmesi çizik oluşturulması sonrası yara yerinin kapanması ile, farklanması kemik hücresi osteoblasta dönüştürülmesiileincelendi.PBolarakNBLProbioticGold.Preparatiç̧ersindeki2.5x109Enterococcus faecium, 2.5x109lactobacillusacidophilus, 2.5x109lactobacillusrhamnosus, 2.5x109Bifidobacterium longum, 2.5x109Bifidobacterium bifidum bakterileri eklenip aynı ortamdaki MKH için davranış parametreleri açısından incelendi. PB ve MKH ilişkisi taramalı elektron mikroskobi ile de araştırıldı. Bulgular: PB eklenmesinin çoğalmayı hızlandırdığı, göç etmeyi arttrarak yara iyileşmesini çabuklaştrdığı ve osteoblastik kemiksi yapıya farklanmada olumlu katkısının oluştuğu saptandı. İnce yapı incelemesinde PB ile etkileşmiş MKH için daha canlı, daha çok tutunan ve daha aktif hücre morfolojisinde olduğu bulundu. Sonuç: Alınan sonuçlar kültür ortamına PB eklenmesinin MKH etkinliğini arttırdığını gösterdi. Deney hayvanıileyapılacakçalışmalardaaynıolumluetkiningörülmesininklinikiçinyararlıolacağıdüşünüldü.

Anahtar Kelimeler: Probiyotik; mezenkimal kök hücre; kültür; davranış; farklanma 
Memeliler birçok bakteri, virüs ve ökaryot hücre içermekte olup mikrobiyata diye isimlendirilmektedirler. Mikrobiyata insan hücre sayısının 10 kat kadardır. Bulundukları dokularda ve oluşturdukları çevrede kan oluşumunda, immun sistemlerin, metabolizmanın ve kemik yeniden yapılanmasında etkili olduğu bilinmektedir. Mikrobiyatanın immün sistemdeki etkisi ve metabolizmadaki yaptı̆̆ değişiklikler iyi bilinmekte olup mikrobiyataya bağlı değişikliklerin kemik üzerindeki etkileri birçok çalışmada ortaya konmuştur. (1) Mikrobiyatanın barsakta gösterdiği etkileri epigenom ve gen ekspresyonu üzerinden gerçekleştiği gösterilmiştir. Mikrobiyal biyoaktif bileşik üretimine bağlı etkileri hücrelerde transkripsiyonel çalşmayı başlattğı saptanmıştr. Barsak mikrobiyatası ile hücre epigenomunun DNA metilasyonu ve histon modifiksyonu ve kodlanmayan RNA ları kullanarak ilişki kurdukları bilinmektedir. Bu durumun anlaşılması ve mekanizmaların incelenmesi klinik kullanımlarını sağlayacak bilgiler getirecektir. (2)

PB, sindirim sisteminde belirli sayıda bulunan ve tüketildiğinde bireyin bağırsaklarındaki bakterilerin sayıca dengesini sağlayarak sindirim sistemi ve bağırsak sağlığını koruyan canlı mikroorganizmalar ve/veya bileşenleri tanımlamaktadır. PB gıda ise içerisinde yeterli miktarda canlı PB mikroorganizma bulunduran ve raf ömrü sonuna kadar bu canlılı̆ı muhafaza eden üründür. Bağırsak florası bozulduğu yani PB azaldığı zaman patojen mikroorganizmalar hızla ürer. Bağırsak florası bozulduğu yani PB azaldığı zaman patojen mikroorganizmalar hızla ürer. Etkin bir PB besinin konakçıya yararlı etkisi olmalı, patojen ve toksik olmamalı ve yüksek oranda canlı mikroorganizma içermelidir. Ayrıca gastrointestinal kanalda asit pH ve safra tuzlarına dirençli olması gereken probiyotik stoklama ve kullanım süresince canlı kalabilmeli ve metabolize etme yeteneğini korumalıdır. PB ve prebiyotik tedavileri ile kemik iyileşmesi barsak mikrobiyatasının kemik metabolizmasında ve sağlıklı kalmasında önemli olduğunu göstermektedir. (3)

Hematopoetik kök hücre transplantasyonu hayat kurtarıcı bir yaklaşım olup önemli komplikasyonlarından birisi transplantasyonlar sonrası enfeksiyonlardır. Bu komplikasyonun oluşmasında barsak mikrobiyatasının önemli bir rol oynadığı ve kullanılan antibiyotikler ile değişen mikrobiyatanın etkili bir faktör olduğu saptanmıştır. Pro ve prebiyotiklerin kullanımı ile daha sağııklı bir mikrobiyatanın oluşturulmasının bu enfeksiyonların önlenmesinde yararlı olduğu düşünülmüştür. (4) Mikrobiyatanın barsakta yaptığı bir başka etkide barsak davranış düzenlenmesinde önemli bir etken olan kök hücre ve Nişi üzerindeki etkileridir. Bu etki ile besin absorbsiyonu, endokrin sinyal, enerji dengesi, immün cevap ve sistemik dengenin gerçekleştiği görülmektedir. (5) Bu düzenin bozulması obesiteden başlayan inflamatuar barsak hastalıkları ve kanser gibi birçok önemli patalojiyi ortaya çıkarmaktadır. Barsak kök hücresinde olan bu olumsuz değişikliklerin mikrobiyata ile düzeltilebilmesi geleceğin tibbında önemli olacaktır. (6)

MKH başlıca kemik iliğinde bulunan pluripotent bir hücre topluluğudur. Bundan başka yağ dokusu, plasenta, amnion sıVısı ve fötal dokularda da bulunur. MKH “ex vivo" kolaylıkla çoğaltılabilir. MKH kesin tanımlayabilen bir hücre belirteci yoktur. Hematopoietik kök hücreden farklı olarak CD34-, CD45- dirler. Henüz tam belirlenememekle beraber tipik yüzey belirteçleri; CD29, CD44, CD71, CD90, CD106, CD124, CD105 (SH2) ve CD73 (SH3/SH4) olarak bildirilmiştir. (7) Rejeneratif tıp hasara uğramış dokuların ve organların biyolojik ürünlerle tedavi edilebilmesine olanak sağlamıştır. Vücudun hasarlanmış hücre, doku ve organlarını kendi kendine onarabilme yeteneği ve kök hücrelerin etkisi incelenerek bu sonuca varılmıştır. Yaşlanma, hastalıklar, travma veya doğuştan bozukluklar nedeni ile fonksiyonlarını yitiren doku ya da organların tamiri ve değişimi için canlı işlevsel dokular üretilmektedir. Yenileyici tıp sadece problem geliştikten sonra hasarın tedavisinde değil aynı zamanda problemlerin oluşmasını engelleyici koruyucu tıp alanında da önemli rol oynamaktadır. KH farklı doku kaynaklarından kolayca elde edilip çok miktarda üretilerek tedavide kullanılacak hale gelen multipotent mezenkimal hücrelerdir. Birçok hastalık için tedavi aşamasına gelmiş ve giderek artan bir şekilde klinikte yer almaktadır. Yağ Kökenli MKH (YKMKH) rejeneratif tıpta özellikle enflamasyonda ve otoimmün hastalıklarda giderek artan önem kazanmaktadır. Osteomiyelit ve kistik fibrosis gibi hastalıklarda bakterinin yavaş üremesine ve koloni oluşturma yeteneğinin azalmasına neden olduğu düşünülmektedir. $\mathrm{KH}$ ve salgıladığı faktörler yan etkileri olmayan tedavi ürünleri olarak klinikte yerlerini almakta ve her geçen gün değişik modifikasyonları ortaya çıkmaktadır. (8) Hasarlı dokularda inflamasyonu azaltıp immün modülasyon ile rejenerasyonu sağlıyabilmektedirler. Yağ dokusu gibi çok farklı kaynaklardan kolayca elde edilebilen KH standardı iyi olan laboratuvarlarda hızlı bir şekilde üretilip hasta için kullanılmak üzere hazır hale getirilmektedir. İskemi, Chron, ülseratif kolit ve karaciğer hastalıkları gibi birçok patolojik durumda faz çalışmaları tamamlanmış ve tedaviler uygulanmaya başlanmıştı. (9)

Kemik iliği kökenli MKH (KiMKH) multipotent farklılaşma yeteneklerinin yanı sıra önemli bir immün modüler kapasiteye sahiplerdir. (3) PB etkilerinin in vivo fare deneyinde gösterildiği bir çalışmada tenofovir indüklenmiş kemik kaybında osteogenez ve proliferasyonu ayrıca osteogenik gen ekspresyonunu artırarak kemik kaybını önlediği anlaşılmıştır. (10) Bir başka çalışmada PB kullanılarak insan periferik mononükleer kan hücreleri kültür ortamında 24 saat inkübasyon sonrasında immün hücreleri aktive ettiği ve antiinflamatuar sitokinler ile kemokinleri dramatik bir şekilde artırdığı görülmüştür. Bu çalışmada görülen ilginç sonuç PB için immünolojik hücre duvarında bulunan lipoteikoik asit üzerinden biyolojik aktivetesini gösterdiği düşünülmüştür. (11) Üç boyutlu orgonoid yapılan bir çalışmada barsak kök hücrelerinin epitel oluşumunda ve miyofibroblast gelişiminde Toll like receptor (TLR) ve Prostaglandin olumlu etki gösterdiği bulunmuştur. (12)

Hastalıkların tedavisinde yeni yaklaşım arayışları probiyotik (PB) ve mezenkimal kök hücre (MKH) tedavisi gibi farklı düşünceleri gündeme getirmektedir. Mikrobiyata ile oluşan biyolojik süreçlerin değişimleri özellikle PB uygulamalarına bağlı farklı etkiler son zamanlarda önemli araştırma konusu olmuştur. Benzer şekilde hücresel tedavi kapsamında MKHGraft Versus Host (GVH) gibi hastalıklarda da olmak üzere birçok tedavide klinik uygulamada yerini almaktadır. Bu çalışmada kültür ortamında MKH davranışına çoğalma, göç etme, farklanma ve yara iyileşmesi açılarından PB uygulamasının yapacağı etkiler araştırıldı. 


\section{GEREÇ ve YÖNTEM}

Probiotic Gold. Preparat içersindeki $2.5 \times 10^{9}$ Enterococcus faecium, $2.5 \times 10^{9}$ Lactobacillus acidophilus, $2.5 \times 10^{9}$ Lactobacillus rhamnosus, $2.5 \times 10^{9}$ Bifidobacterium longum, $2.5 \times 10^{9}$ Bifidobacterium bifidum bakterileri kullanıldı. Değişik dilüsyonda PB uygulaması 1/10, 1/100, 1/1000 konsantrasyonlarında kültür ortamına uygulandı.

Çalışmamızda $-80 \mathrm{C}^{\prime}$ de dondurularak saklanmış dördüncü pasajdaki yağ dokusu mezenkimal kök hücreleri kullanılacak. $-80 \mathrm{C}^{\circ}$ den alınan vial içerisindeki hücreler $37 \mathrm{C}^{\circ}$ deki su banyosunda oda sıcaklığına getirilerek çoğalması ve konfluent olmasını sağlamak için \%15 fötal buzağı serumu (FCS), 50 gr./ml. Gentamisin, $100 \mathrm{UI} / \mathrm{ml}$. Penisilin, $100 \mathrm{UI} / \mathrm{ml}$. Streptomisin, $100 \mathrm{UI} / \mathrm{ml}$. Amfoterisin içeren $\alpha$-MEM kültür ortamına bırakıldı ve $370 \mathrm{C}^{\prime}$ de ve \%5 CO2 koşulunda inkübe edildi. Morfolojik olarak faz kontrast ataçmanlı inverted mikroskopta incelenerek fotoğrafi çekildi. (13)

MTT Assay Sitotoksik etkiler, sitotoksisitenin değerlendirilmesinde yaygın olarak kullanılan enzimatik test yöntemlerinden biri olan MTT [3-(4,5-dimetiltiazol-2-il)- difenil tetrazolium bromid] assay yöntemi ile belirlendi. Bu yöntem, MTT boyasının tetrazolium halkasını parçalayabilmesi ilkesine dayanmakladır. Bu yöntemde, MTT canlı hücrelere aktif olarak absorbe olur ve reaksiyon mitokondriyal süksinat dehidrogenaz tarafindan katalize edilerek mavi-mor renkli, suda çözünmeyen formazana indirgenir. Formazan oluşumu, yalnızca aktif mitokondrinin bulunduğu canlı hücrelerde görülmektedir. Bu da hücre canlılığının bir belirteci olarak kabul edilmekte ve spektrofotometrik olarak belirlenen değer yasayan hücre sayısı ile ilişkilendirilmektedir. Steril PBS içerisinde hazırlanan stok MTT solüsyonundan, 0,5 mg/mL MTT çalışma solüsyonu hazırlandı ve 96 kuyucuklu plaklara ilave edildi. İnkübatörde 3 saat bekletildikten sonra plakalardaki hücrelerin optik dansiteleri ELISA cihazında (Bio-Rad, ABD) $540 \mathrm{~nm}$ dalga boyunda okutuldu. Kontrol kuyucukları okutularak elde edilen absorbans değerlerinin ortalaması alındı ve bu değer \%100 canlı hücre olarak kabul edildi. Çözücü ve ajan uygulanan kuyucuklardan elde edilen absorbans değerleri kontrol absorbans değerine oranlandı ve yüzde canlılık olarak kabul edildi. MTT denemeleri farklı günlerde en az 10 kez tekrarlandı ve test maddelerinin prostat kanseri hücreleri üzerine sitotoksik etkilerinin olup olmadığı tespit edilmeye çalışıldı. (14)

MKH kültür ortamında konfluent olduğunda pipet ucu ile yapılacak çizik fotoğraflanarak uygulama sonrası yaranın

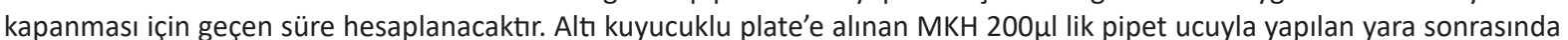
besiyeri değiştirilerek iyileşme sürecine bırakıldı. Kapanmanın tamamlandığı ilk örnekte diğer örneklerin fotoğrafları çekilerek iyileşme süreci incelendi. (15)

MKH için osteojenik farklanmada askorbik asit, beta gliserofosfat ve dexamethazon ilavesi yapılan besiyeri kullanıldı. Farklanmanın belirteçleri olarak Alizerin Red (AR) ve Von kossa (VK) ile osteokalsin (OK) ve Osteonektin (ON) belirteçleri kullanıldı. (13)

\section{BULGULAR}

MKH kültür ortamında üretilip semikonflient ve konflient hale getirildi. Karakterizasyon için Stro-1, CD73 ve CD90 pozitifliği ve CD34 ile CD45 negatifliği kullanıldı (Resim 1). Büyük çoğunlukla homojen bir MKH oluştuğu ve PB uygulamasının parametreleri olumlu etkilediği saptandı (Tablo 1). görüldü.

MTT ile yapılan ölçümlerde PB kullanımının hücre çoğalmasını (Resim 2) anlamlı bir şekilde arttırdığı (Tablo 2)

MKH kültür ortamında konfluent olduğunda pipet ucu ile yapılan çizik yara modelinde (Resim 3) PB kullanımının yaranın kapanması için geçen süreyi kısalttı̆ı ve iyileşmeyi hızlandırdığı (Tablo 3) bulundu.

PB uygulamasının osteojenik farklanmaya olan etkisini incelemek için yapılan AR ve VK ile ON ve OK (Resim 4) boyamalarında anlamlı bir etki (Tablo 4) izlendi.

PB uygulamasının EM incelemesinde (Resim 5) hücrelerin morfolojisinin, adezyonunun ve canlılığının belirgin olarak daha iyi olduğu görüldü.

\section{TARTIŞMA}

Hastalıkların tedavisinde yeni yaklaşım arayışları PB ve MKH tedavisi gibi farklı düşünceleri gündeme getirmektedir. Mikrobiyata ile oluşan biyolojik süreçlerin değişimleri özellikle PB uygulamalarına bağlı farklı etkiler son zamanlarda önemli araştırma konusu olmuştur. Benzer şekilde hücresel tedavi kapsamında MKH Graft Versus Host (GVH) gibi hastalıklarda da olmak üzere birçok tedavide klinik uygulamada yerini almaktadır. Bu çalışmada kültür ortamında MKH davranışına çoğalma, göç etme, farklanma ve yara iyileşmesi açılarından PB uygulamasının yapacağı etkilerin incelenmesi amaçlandı. PB eklenmesinin çoğalmayı hızlandırdığı, göç etmeyi arttırarak yara iyileşmesini çabuklaştırdığı ve osteoblastik kemiksi yapıya farklanmada olumlu katkısının oluştuğu saptandı. İnce yapı incelemesinde PB ile etkileşmiş MKH için daha canlı, daha çok tutunan ve daha aktif hücre morfolojisinde olduğu bulundu.

PB verilen dokunun sağlıklı olması için patojen bakterilerle mücadele eden mikroorganizmalardır. Lactobacillus, Bifido, E coli, Enterocoocus fecalis gibi PBler uygun doz ve karışımda kullanıldığında antimikrobiyal faktörler salgılayarak ve immün cevabı modüle ederek dokunun iyileşmesine ve sağlıklı olmasını sağlarlar. Birçok çalışmada PB için özellikle 
PB -

Stro-1
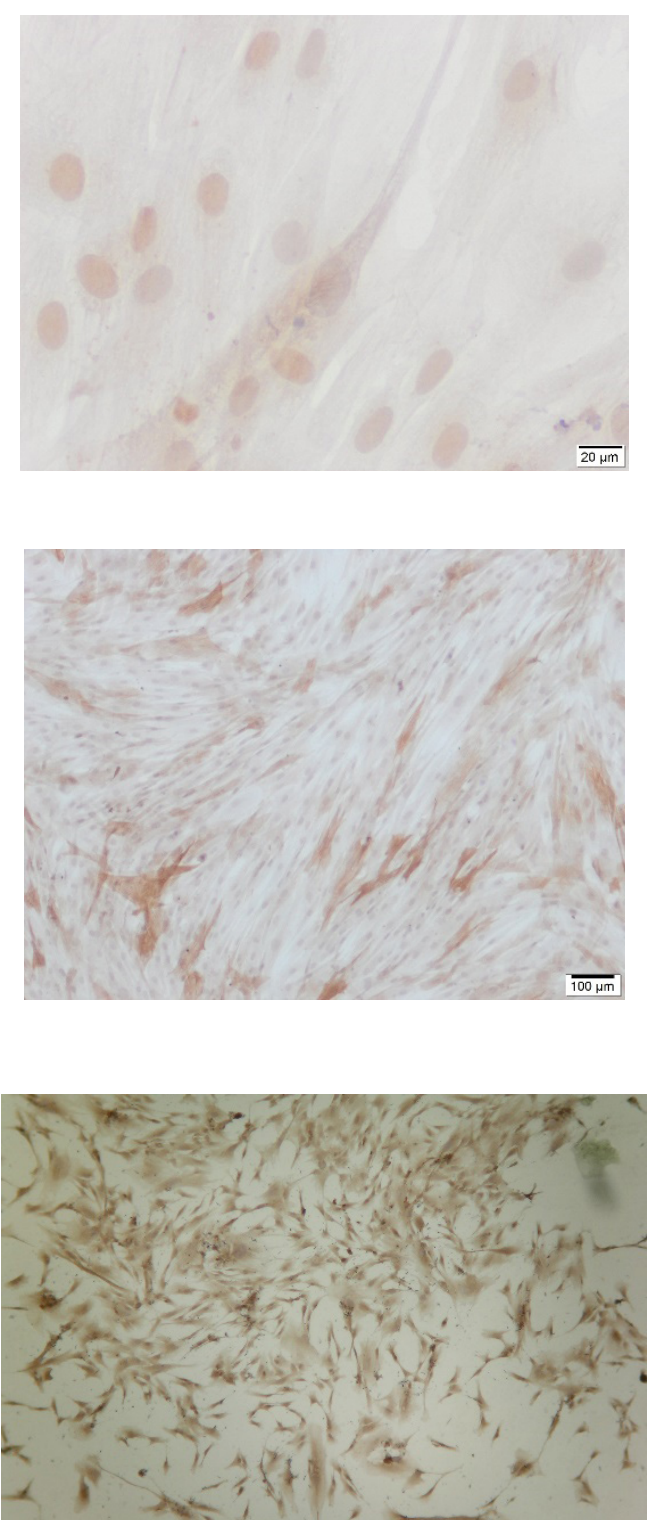

CD73

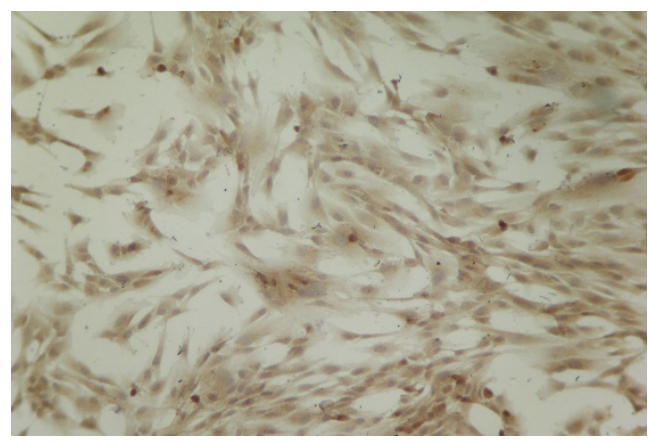

CD45
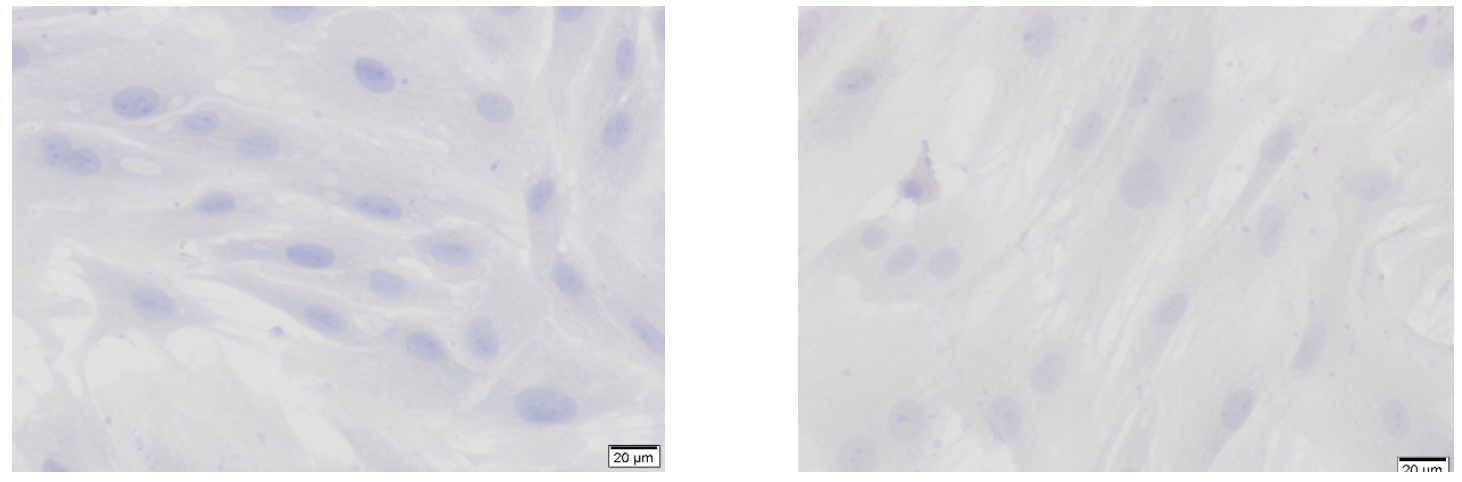

CD34
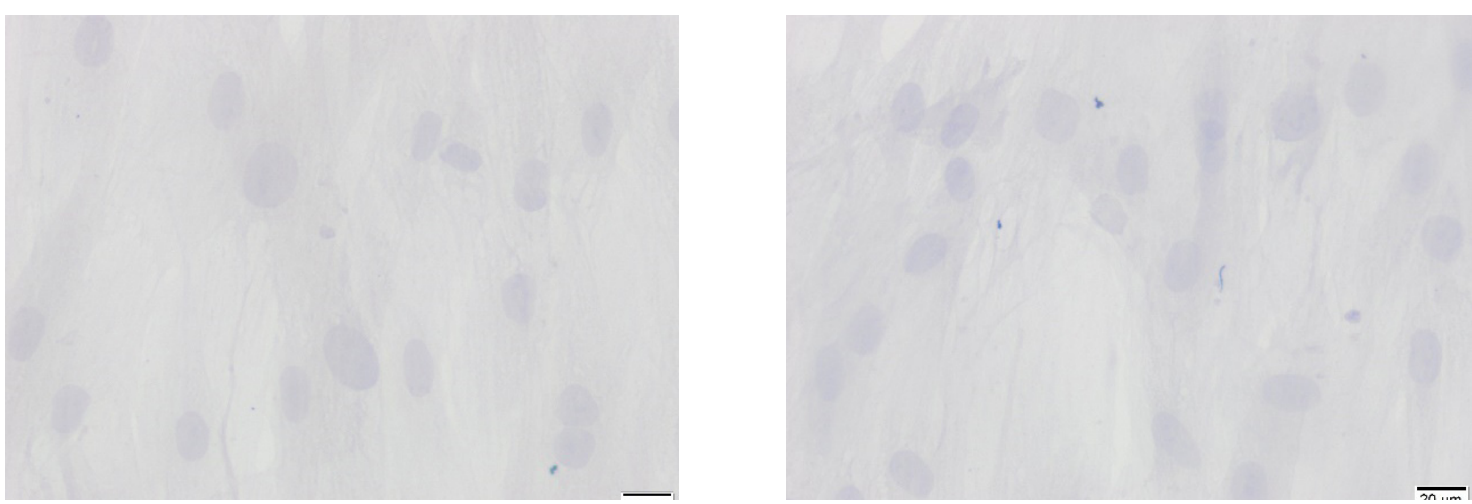
Tablo 1. MKH belirteçlerinin IHK ile tanımlanması sonrasında PB etkisi h-Skor ile yapılan değerlendirme

\begin{tabular}{|l|c|c|c|c|c|}
\hline h-skor & Stro-1 & CD90 & CD73 & CD45 & Cd34 \\
\hline PB- & $155.78 \pm 24.86$ & $226.85 \pm 22.92$ & $205.84 \pm 18.42$ & $11.96 \pm 4.78$ & $6.05 \pm 2.88$ \\
\hline PB+ & $198.22 \pm 18.36$ & $266.66 \pm 16.91$ & $228.24 \pm 16.45$ & $16.28 \pm 3.86$ & $9.12 \pm 3.14$ \\
\hline
\end{tabular}

karsinojenik bakteriler açısından çoğalma ve adezyonu azaltthkları gösterilmiştir. Özellikle oral muloza enfeksiyonlarından candidiasizde kültür ortamında kullanılan PB için büyüme, çoğalma ve adezyonu azalttığı ayrıca biyofilm formasyonunu düşürdüğü saptanmıştır. Yara iyileşme sürecinde yara kenarlarında adezyon, göç ve farklılaşmayı yönlendirerek in vivo iyileşmeyi hızlandırdığı gösterilmiştir. (16)

PB -

\section{Morfoloji}

semikonfluent
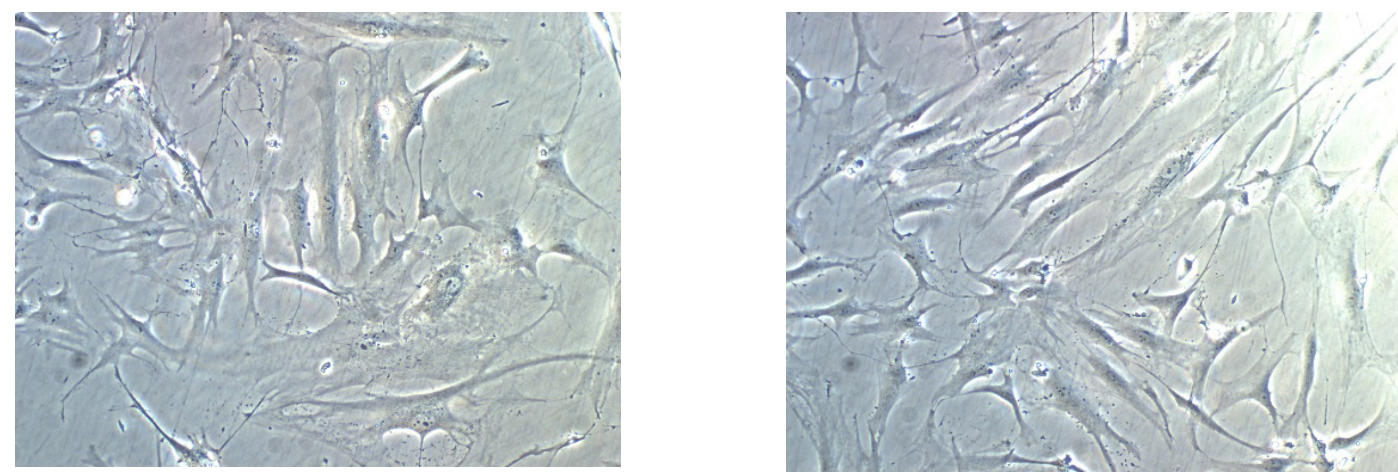

konfluent
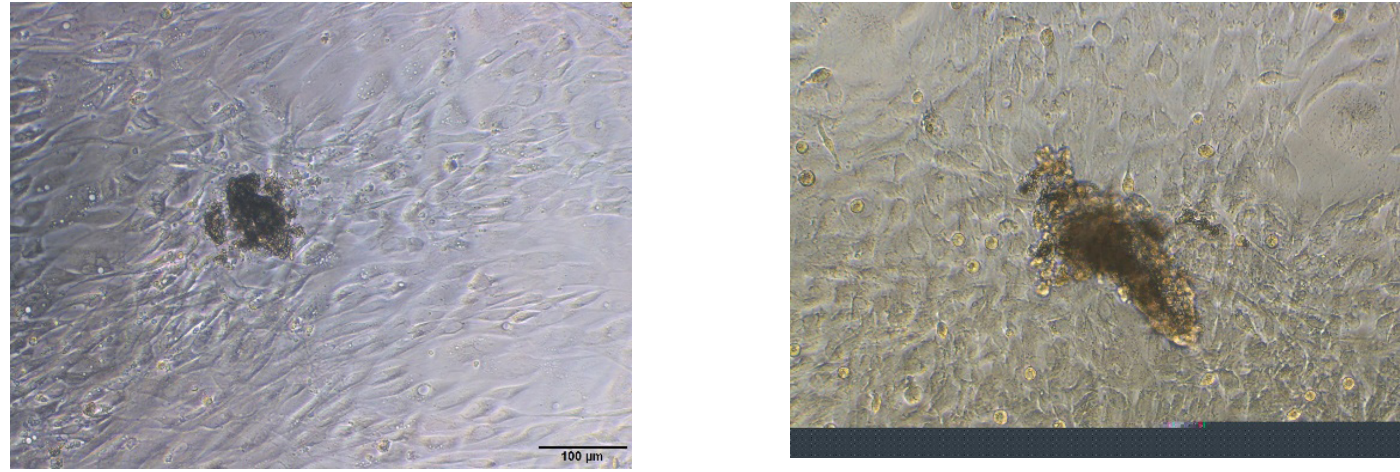

Resim 2 MKH Farklanma sürecinde Osteoblastik değişim (G3) ve kemiksi koloni oluşumu (G7)

Tablo 2. MKH Farklanma sürecinde Osteoblastik değişim (G3) ve kemiksi koloni oluşumu (G7) PB etkisi için MTT

\begin{tabular}{|c|c|c|}
\hline MTT & G3 & G7 \\
\hline PB- & $564.46 \pm 124.22$ & $1244.48 \pm 148.12$ \\
\hline PB+ & $778.36 \pm 128.77$ & $1366.26 \pm 154.68$ \\
\hline
\end{tabular}

MKH için göç etmenin ve gittiği doku uyum sağlamanın rejeneratif tıp açısından önemi çok büyüktür. PB kullanımının migrasyon kapasitesini arttırması etki mekanizmalarından birisi olmaktadır. Lactobasillus için kültür ortamında makrofaj ve lenfositleri çoğalmak üzere sitümüle ettiği ve böylelikle kemotaksis ve anjiogenesizi yönlendirdiği gösterilmiştir. Yapılan bir çalışmada yüzey belirteçleri ile karakterize edilen umblikal kord MKH ları için adipojenik ve osteojenik farklanma araştrımıştır. Yapılan uygulamalarda farklı etkenler kullanılmasına rağmen MKH için morfolojik bir farklılık gözlenmez iken göç belirteçlerini farklı bir şekilde eksprese etmişlerdir. Değişik düzeylerde VLA-4 ve VCAM-1 göç belirteçlerini PCR ile tanımlamışlardır. L. asidop ile VEGF ve MMP-2 artarken CXCR-4 bir değişiklik oluşmamıştır. Bu çalışmadan PB kullanımının migrasyon için önemli bir faktör olduğu ortaya konmuştur. PB ile artan migrasyon kapasitesinin adipojenik ve osteojenik farklanmayı da artırdığı düşünülmüştür. (17) Kültür ortamında çizik oluşturma yöntemi MKH için göç etme yeteneğinin araştııımasında kullanılmaktadır. Bu amaçla yapılan bir çalışmada Lactobacillus reuteri ve Porphyromonas ekstraktı kullanımının MKH çoğalma ve farklanma aktivitesinin yanı sıra göç etme yeteneğini de arttırdığı bulunmuştur. Kültür ortamında çizik yarasının kapanmasını 
hızlandırdığı gibi invivo deri yara iyileşmesinde benzer şekilde yaptığı saptanmıştr. Her iki durumda da P.gingivalis içindeki LPS ile NLPR3 inflamasomun aktive olup MKH fonksiyonu inhibe edildiğinde bu göç etkisinin oradan kalktığı gözlenmiştir. PB etkisinin mikrobiyata dengesini sağlayarak inflamasyonu ve yara iyileşmesini olumlu yönde etkilediği düşünülmüştür. (16)

PB -
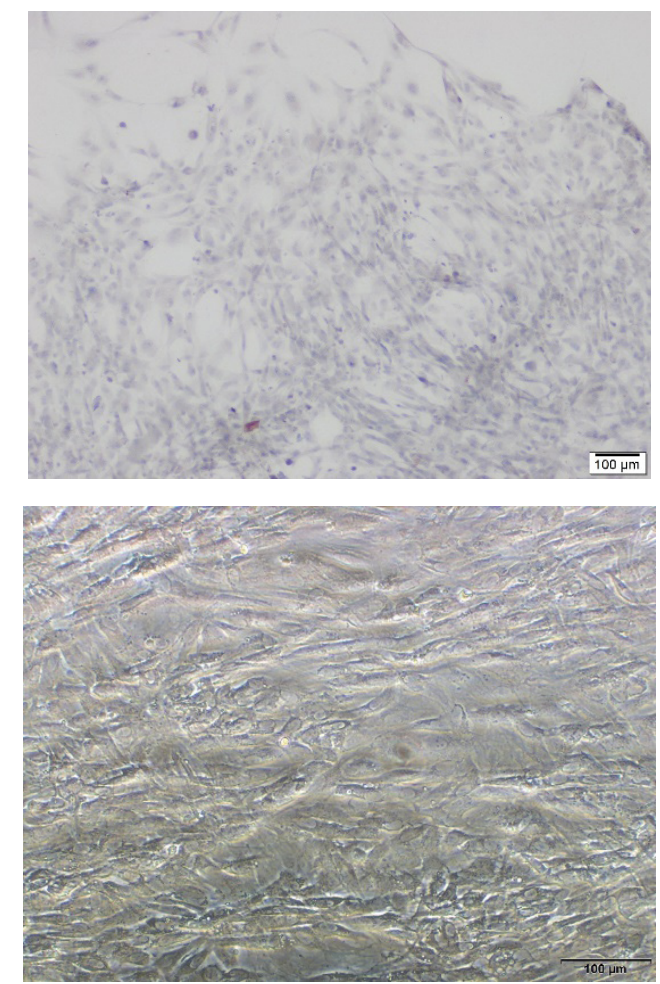

$\mathrm{PB}+$

Göç
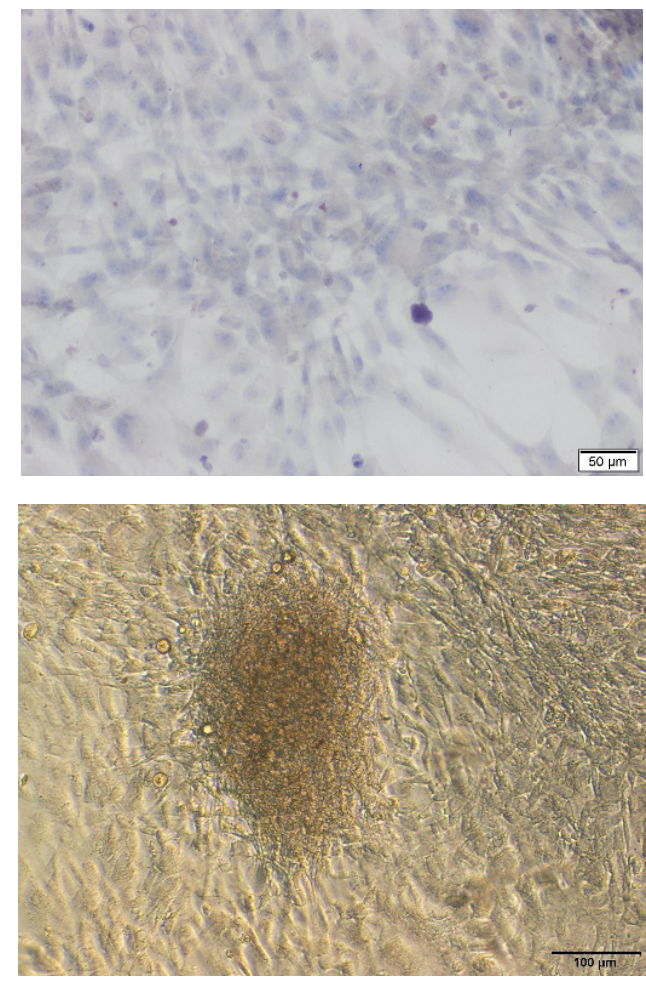

Resim 3. MKH Farklanma sürecinde çizik sonrası göç etme ve farklanmanın saptanması

Tablo 3. MKH Farklanma sürecinde çizik sonrası göç etme ve farklanmanın morfometrik analizinde yara kenarından başlayan çoğalma ve göçün yara kapanmasını sağlaması ve oluşan kemiksi adacıkların ölçümleri ile PB etkisinin gösterilmesi.

\begin{tabular}{|c|c|c|}
\hline Çizik & Yara kapanması & Kemiksi Adacık Oluşumu \\
\hline PB - & $0.48 \pm 0.17 \mu \mathrm{m}$ & $23.22 \pm 8.94$ \\
\hline PB + & $0.31 \pm 0.11 \mu \mathrm{m}$ & $32.18 \pm 7.64$ \\
\hline
\end{tabular}

PB kullanımının mikrobiyata homeastazını sağlamasının dışında patolojik durumlarda da hücre proliferasyonunu ve osteojenik farklanmayı arttırarak hasarı önleyici özelliğide bulunmaktadır. Tenofovir ile indüklenmiş mandibula kemik kaybında PB kullanımının mandibuler MKH için indükleyici özelliğinden yararlanarak kemik kaybının azaltıldığı gösterilmiştir. Mandibular histomorfometri için yapılan mikroCT ile yapılan osteojenik belirteçler için yapılan PCR ve süpernatanttan yapılan ALP üretimi ile L.rhamnosus GG PB için supernatant a salgıladığı faktörlerin osteogenezi yeniden yapılandırdığı gösterilmiştir. (10) PB tarından salgılanan faktörler açısından bakıldığında farkın metabolitlerden kaynaklandığı belirlenmiştir. Farklı PB kültür ortamına eklenip bir süre sonraki süpernatant toplanarak MKH için uygulandığında çoğalmanın ve farklanmanın arttrıldığı saptanmıştır. Çoğalma için PCNA ve kök hücre içinde SOX-2, OCT-4 ve NANOG transkripleri için kullanılmış ve IPKH için farklanması saptanmıştır. (18)

Yapılan bir çalışmada P.gingivalis ve L reuteri olarak PB kullanımının kültür ortamında gingival MKH için çoğalma, göç etme ve osteojenik farklanmayı hızlandırdığı saptanmıştır. Osteojenik farklanmanın kritik transkripsiyon faktörlerinde olan OSX, OPN, OCN ve RUNX2 belirteçlerini Real time RT-PCR ile gösterildiği üzere anlamlı bir şekilde artırmıştr. Red O boyaması ile patojenik bakteri ile PB arasında kurulan dengeye bağlı olarak MKH için adipojenik farklanmanın baskılandığı gösterilmiştir. Bu sonuçlara ilişkin olarak fare damağında yapılan yara iyileşmesi deneyinde L.reuteri ve P.gingivalis gruplarının iyileşmeyi hızlandırdığı gösterilmiştir. Böylelikle oral mikrobiyom dengesinin sağlanması ile yara iyileşmesinin sağlandığı düşünülmüştür. NLRP3 aktivatörü olarak kullanılan LPS ile MKH göçünü anlamlı bir şekilde inhibe ettiği saptanmıştır. Benzer şekilde OSX, OPN, OCN ve RUNX2 belirteçleri baskılanmıştr. L.reuteri kullanımı ile MKH için oluşan tüm olumsuzluklar geri döndürülmüştür. L.reuteri nin P.gingivalis teki LPS yi nötralize ederek patojenik bakteri ve PB arasındaki dengeyi sağlıyarak yara iyileşmesini hızlandırmaktadır. (16) 
PB -

AR
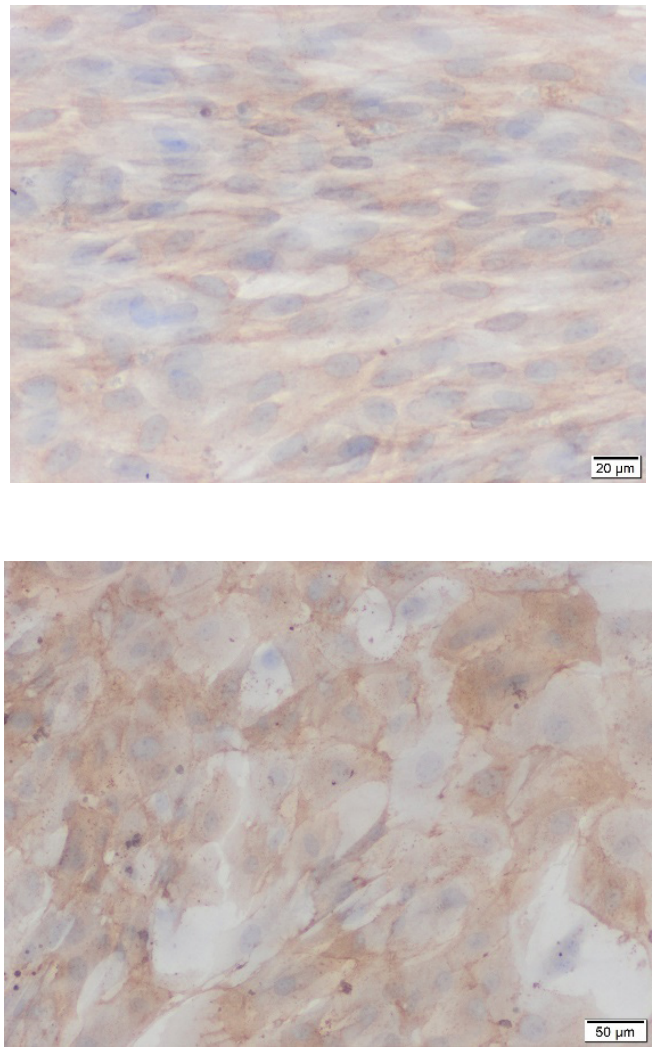

VK

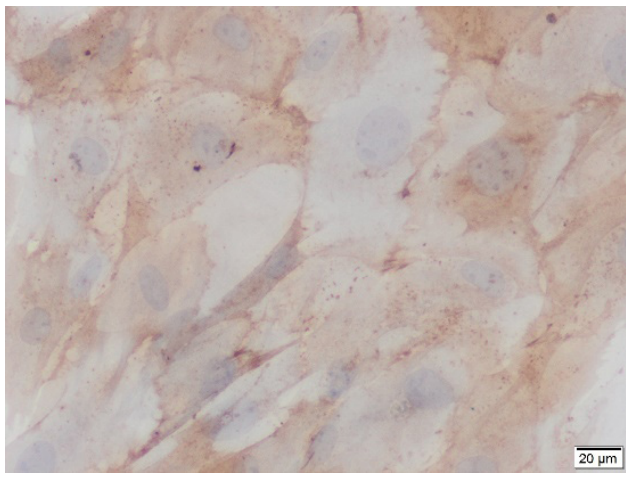

ON
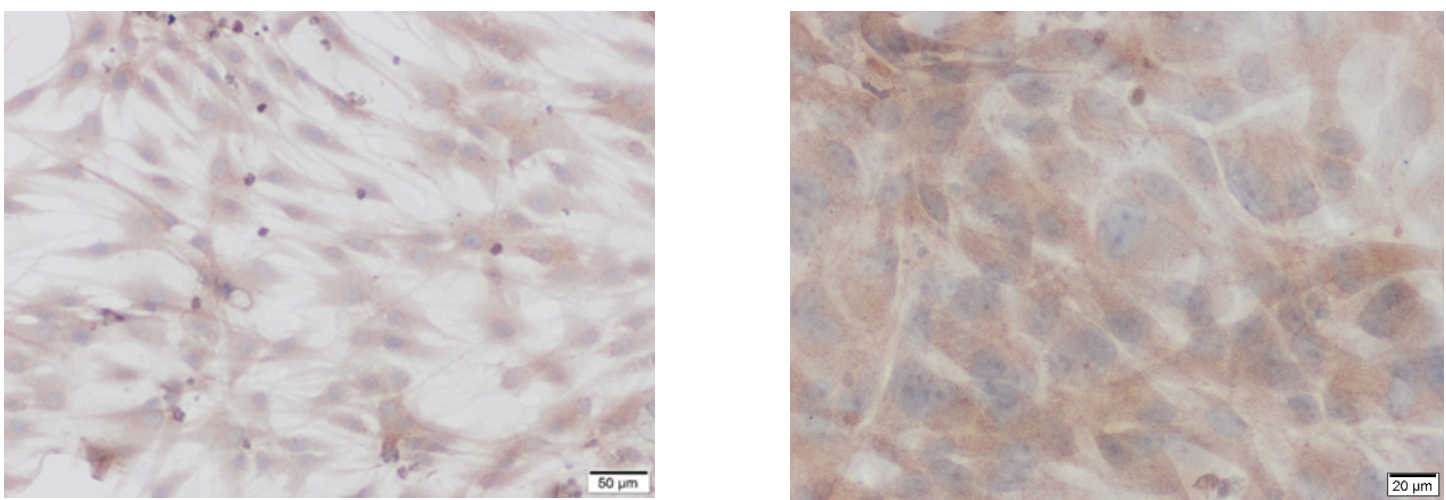

OK
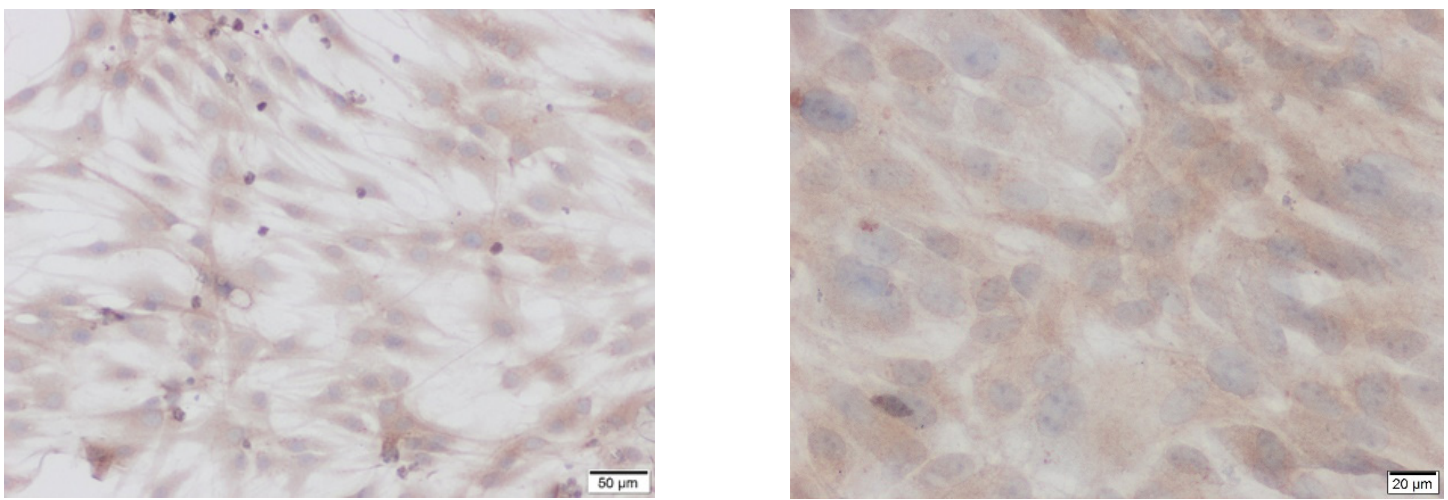

Resim 4. MKH için osteoblastik farklanma kriterleri olan AR ve VK Histokimyası ile ON ve OK immünohistokimya görüntüleri

Tablo $4 \mathrm{MKH}$ için osteoblastik farklanma kriterleri olan AR ve VK Histokimyası ile ON ve OK immünohistokimya görüntülerinde yapılan h-Skor analizi ile PB etkisinin gösterilmesi

\begin{tabular}{|c|c|c|c|c|}
\hline h-skor & AR & VK & ON & OK \\
\hline PB - & $65.78 \pm 16.92$ & $55.77 \pm 11.45$ & $148.84 \pm 24.37$ & $124.66 \pm 15.44$ \\
\hline PB + & $94.98 \pm 18.88$ & $68.87 \pm 13.42$ & $162.66 \pm 18.48$ & $138.11 \pm 12.94$ \\
\hline
\end{tabular}




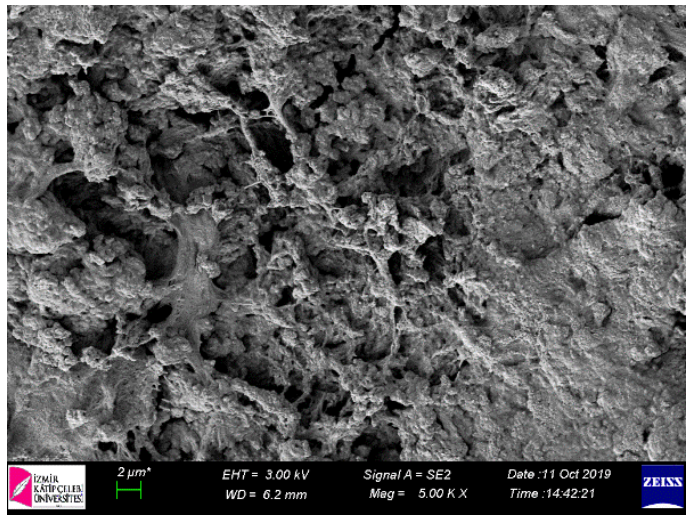

Morfoloji
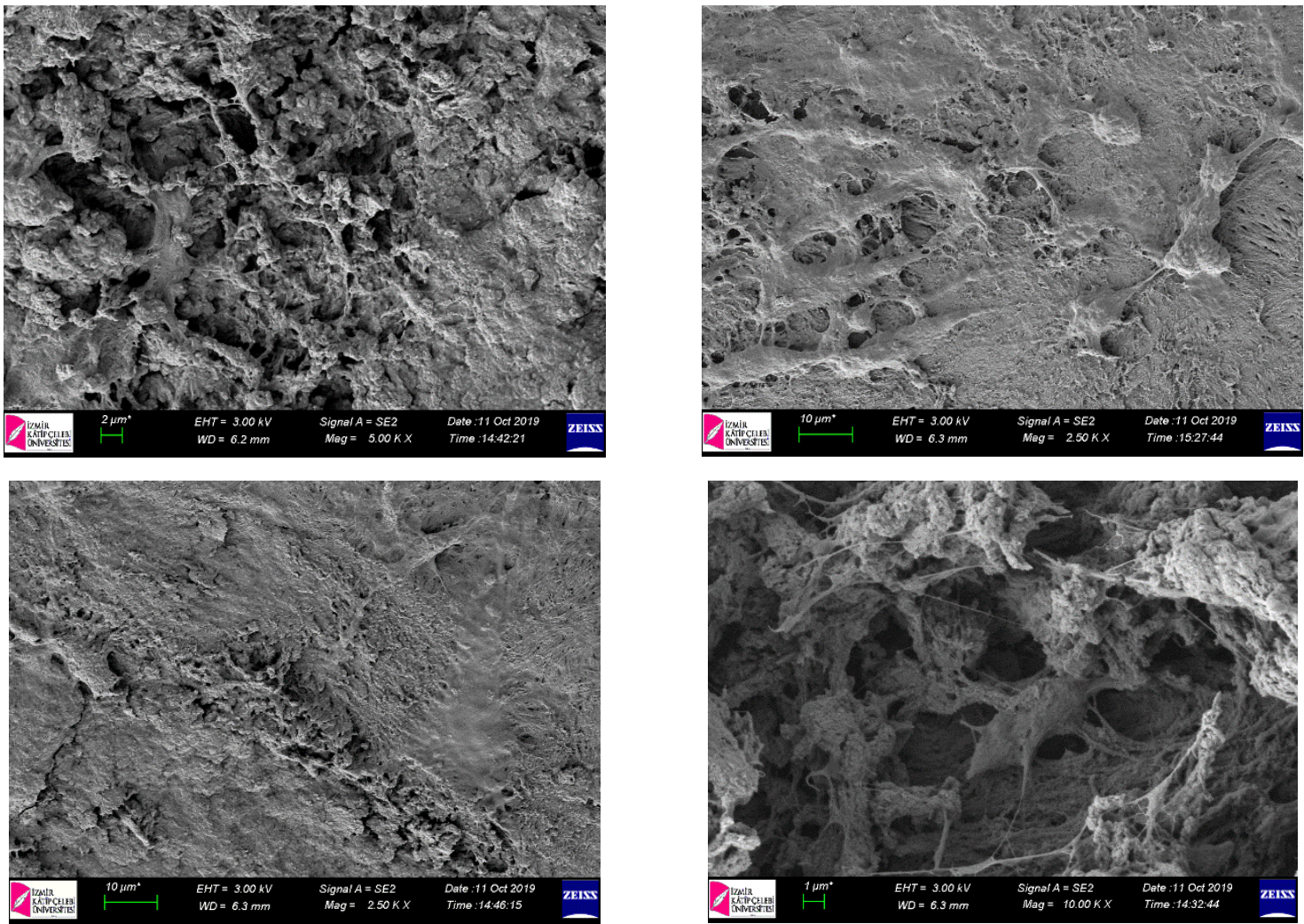

Resim 5 SEM ile kültür ortamında PB etkisinin gösterilmesi.PB eklenmesinin çoğalmayı hızlandırdığı, göç etmeyi arttırarak yara iyileşmesini çabuklaştırdığı ve osteoblastik kemiksi yapıya farklanmada olumlu katkısının oluştuğu saptandı. İnce yapı incelemesinde PB ile etkileşmiş MKH için daha canlı, daha çok tutunan ve daha aktif hücre morfolojisinde olduğu bulundu.

Osteoblastik farklanma kemik bütünlüğünün korunmasında önemli bir faktör olup Propionibacterium freudenreichii ile ilişkisinin araştırıldığı bir çalışmada çiğ sütten elde edilen MJ2 izolatının osteoblastik farklanma, mineralizasyon ve sinyal yolağını etkilediği invitro ve invivo gösterilmiştir. Osteoblastik farklanma ve minealizasyon q-PCR ve western blot ile incelendiğinde osteoprotegerin osteoblastik belirtecinin ve nuklear faktör kB ligandının anlamlı bir şekilde arttığı ayrıca BMP2 nin yükseldiği saptanmıştır. Alizerin red boyaması ile mineralizasyonu artırdığı bulunmuştur. Overektomili sıçanlarda ağızdan MJ2 beslemesinin oluşan osteoporozu azalttığı bulunmuştur. (19) Osteopozlu hastalardan alınan 25-OH vitamin D ve prokollajen tip 1 enterminal peptid örneklerinde Lactobacillus asidophilus ve ramnossus etkisi MC3T3-E1 ve osteoblastlar ve RAW 264.7 osteoklaslar etkisi incelendiğinde bütirik asit üzerinden osteoblastik olgunlaşmayı sağladıkları saptanmıştr. ALP aktivitesinin arttğı OK konsantrasyonunun yükseldiği ve RUNX2, RANK, NFATc1, cathepsin K, DC-STAMP, OSCAR, WNT2 ve CTNNB1 yükseldiği osteoblastlarda gösterilmiştir. Osteoklastlar içinde tersi gerçekleşmiştir. (20)

Insan kemik iliği MKH osteoblastik farklanmasında PLLA scaffoldu ile verilen probiyotik nisin tedavisinin osteoblastik farklanmada etkili olduğu gösterilmiştir. MTT ölçümleri ile kültürün birinci ve 3., 5. Günlerinde nişin tedavisinin çoğalmayı artrrıcı etkisi saptanmıştır. RT-PCR ile ALP, ON, OK ve kollajen 1 ekspresyonlarının anlamlı bir şekilde arttığı buna karşıık RUNX2 gen ekspresyonun azaldığı gösterilmiştir. AR ve vonkossa testleri ile minerilizasyonun arttığı saptanmıştı. SEM ile hücrelerin çoğalma eğiliminde olduğu ve daha aktif bir hücre yapısı gösterdiği belirlenmiştir. (21) Bu çalışmanın sonuçları bizim bulgularımız ile oldukça paralel olup bir scaffold kullanmadan ve PB karışımı ile daha iyi sonuçlar aldığımız görülmektedir.

\section{SONUÇ}

Bu çalışmada kültür ortamında MKH karakteristliği ve osteoblastik farklannma üzerine probiyotik karışımının etkisi incelendi. PB karışımının MKH belirteçlerini anlamlı bir şeklde yükselttiği h-Skorlama ile bulundu.

MKH farklanması için osteoblastik değişim süreci incelendi ve PB lerin MTT ile çoğalmanın, çizik atma ile göç etmenin, AR ve VK ile mineralizasyonun ayrıca ON ve OK ile osteoblastik farklanmanın anlamlı bir şekilde arttırıldığı saptandı.

Alınan sonuçların kemik gelişimi, patolojik durumları ve özellikle osteoporoz için önemli bir anlam ifade ettiği düşünüldü. Alınan sonuçlar MKH tedavisi gerektiren durumlarda PB kullanılmasının tedavi etkinliğini arttırdığı kültür ortamında anlaşıldı. Deney hayvanı ile yapılacak çalışmalarda aynı olumlu etkinin görülmesinin klinik için yararlı olacağı düşünüldü. 


\section{BILDIRIMLER}

Çıkar Çatışması: Yazarlar arasında çıkar çatışması yoktur.

Finansal Destek: İzmir Demokrasi Üniversitesi BAP Komisyonundan maddi destek alınmıştır.

Etik Onay: Çalışmanın konusu itibari ile etik onay alınamasına gerek yoktur.

\section{KAYNAKLAR}

1.Tan Y, Wei Z, Chen J, An J, Li M, Zhou L, Men Y, Zhao S. Save your gut save your age: The role of the microbiome in stem cell ageing. J Cell Mol Med. 2019 Jun 17.

2.Qin Y, Wade PA. Crosstalk between the microbiome and epigenome: messages from bugs. J Biochem. 2018 Feb 1;163(2):105112.

3.Xiao E, He L, Wu Q, Li J, He Y, Zhao L, Chen S et al.Microbiota regulates bone marrow mesenchymal stem cell lineage differentiation and immunomodulation. Stem Cell Res Ther. 2017 Sep 29;8(1):213.

4.Andermann TM, Rezvani A, Bhatt AS. Microbiota Manipulation With Prebiotics and Probiotics in Patients Undergoing Stem Cell Transplantation. Curr Hematol Malig Rep. 2016 Feb;11(1):19-28. doi: 10.1007/s11899-016-0302-9. PMID: 26780719;

5.Peck BCE, Shanahan MT, Singh AP, Sethupathy P. Gut Microbial Influences on the Mammalian Intestinal Stem Cell Niche. Stem Cells Int. 2017; 2017:5604727

6. Hou Q, Ye L, Huang L, Yu Q. The Research Progress on Intestinal Stem Cells and Its Relationship with Intestinal Microbiota. Front Immunol. 2017 May 23; 8:599.

7.Karaöz, E., Aksoy, A., Ayhan, S., Sariboyaci, AE., Kaymaz, F., Kasap, M.). Characterization Of Mesenchymal Stem Cells From Rat Bone Marrow: Ultrastructural Properties, Differentiation Potential And Immunophenotypic Markers, Histochemistry and Cell Biology, 2009; 132: 533-46.

8. Michael S, Achilleos C, Panayiotou T, Strati K. Inflammation Shapes Stem Cells and Stemness during Infection and Beyond. Front Cell Dev Biol. 2016; 4:118.

9. Sureda, A., Bader, P., Cesaro, S. et al. Indications for allo- and auto-SCT for haematological diseases, solid tumours and immune disorders: current practice in Europe, 2015. Bone Marrow Transplant 50, 1037-1056 (2015). https://doi.org/10.1038/ bmt.2015.6

10.Liu H, Gu R, Li W, Zhou W, Cong Z, Xue J, Liu Yet al. Lactobacillus rhamnosus GG attenuates tenofovir disoproxil fumarateinduced bone loss in male mice via gut-microbiota-dependent anti-inflammation. Ther Adv Chronic Dis. 2019 Jul 3;10

11.Jensen GS, Cash HA, Farmer S, Keller D. Inactivated probiotic Bacillus coagulans GBI-30 induces complex immune activating, anti-inflammatory, and regenerative markers in vitro. J Inflamm Res. 2017 Aug 7;10: 107-117.

12.Pierzchalska M, Panek M, Czyrnek M, Grabacka M. Correction to: The Three-Dimensional Culture of Epithelial Organoids Derived from Embryonic Chicken Intestine. Methods Mol Biol. 2019; 1576:355.

13.Karakayali M, Önal T, Tuglu Mi. Effect of mesenchymal stem cells and their niche on diabetic and osteoporotic wound healing following osteogenic differentiation and bone matrix formation in vitro. 2019, Cilt 13, Sayı 3, 183- 192

14.Karakayali M, Önal T, Tuglu Mi. Investigation of the moderate toxicity of agricultural pesticides cyantraniliprole, boscalid and spiromesifen in vitro using neurotoxicity screening test, 2021, Cilt 15, Sayı 1, $1-10$.

15.Mete M, Aydemir I, Ünlü Ünsal Ü, Duransoy YK, Tuğlu IM, Selçuki M. Neuroprotective effects of bone marrow-derived mesenchymal stem cells and conditioned medium in mechanically injured neuroblastoma cells. Turk J Med Sci. 2016 Dec 20;46(6):1900-1907. doi: 10.3906/sag-1507-187.

16. Han N, Jia L, Guo L, Su Y, Luo Z, Du J, Mei S et al. Balanced oral pathogenic bacteria and probiotics promoted wound healing via maintaining mesenchymal stem cell homeostasis. Stem Cell Res Ther. 2020 Feb 14;11(1):61. doi: 10.1186/s13287-0201569-2.

17.Atesci AA, Avci CB, Tuglu MI, Ozates Ay NP, Eronat AC. Effect of Different Dentin Conditioning Agents on Growth Factor Release, Mesenchymal Stem Cell Attachment and Morphology. J Endod. 2019 Dec 4. pii: S0099-2399(19)30843-X. doi: 10.1016/j.joen.2019.10.033. 
18.Wu ZY, Sun Q, Liu M, Grottkau BE, He ZX, Zou Q, Ye C. Correlation between the efficacy of stem cell therapy for osteonecrosis of the femoral head and cell viability. BMC Musculoskelet Disord. 2020 Jan 29;21(1):55.

19.Yeom J, MaS, Lim YH. Probiotic Propionibacterium freudenreichii MJ2 Enhances Osteoblast Differentiation and Mineralization by Increasing the OPG/RANKL Ratio. Microorganisms. 2021 Mar 24;9(4):673. doi: 10.3390/microorganisms9040673. PMID: 5.Oliveria PD

20.Chen C, Dong B, Wang Y, Zhang Q, Wang B, Feng S, Zhu Y. The role of Bacillus acidophilus in osteoporosis and its roles in proliferation and differentiation. J Clin Lab Anal. 2020 Nov;34(11): e23471. doi: 10.1002/jcla.23471. Epub 2020 Aug 11.

21.Fariba Sadraei, Marzieh Ghollasi ,Karaj Fatemeh Khakpai https://orcid.org/0000-0002-3363-8276 Osteogenic Differentiation of Pre-Conditioned Bone Marrow Mesenchymal Stem Cells with Nisin on the Modified Poly-L-Lactic-Acid Nanofibers Research Square, 2021. 